\title{
(-)-Verrucosan-2 $\beta$-ol from the phototrophic bacterium Chloroflexus aurantiacus: first report of a verrucosane-type diterpenoid from a prokaryote
}

\author{
Jens Hefter, ${ }^{1}$ Hans H. Richnow, ${ }^{1}$ Ulrich Fischer, ${ }^{2}$ Jean M. Trendel ${ }^{3}$ \\ and WALTER MiCHAELIS ${ }^{1 *}$ \\ ${ }^{1}$ Institut für Biogeochemie und Meereschemie, Universität Hamburg, Bundesstraße 55, 20146 Hamburg 13, Germany \\ ${ }^{2}$ ICBM und Fachbereich Biologie, Arbeitsgruppe Geomikrobiologie, Universität Oldenburg, Postfach 2503, 26111 \\ Oldenburg, Germany \\ ${ }^{3}$ Institut de Chimie, Université Louis Pasteur de Strasbourg, 1 Rue Blaise Pascal, 67008 Strasbourg Cedex, France
}

(Received 14 April 1993; revised 15 June 1993; accepted 28 June 1993)

(-)-Verrucosan-2 $\beta$-ol $\left(\mathrm{C}_{20} \mathrm{H}_{34} \mathrm{O}\right)$, a rare diterpene with a 3,6,6,5-tetracyclic ring system, has been isolated and identified for the first time from the phototrophic bacterium Chloroflexus aurantiacus. Furthermore, an unsaturated diterpenoid hydrocarbon $\left(\mathrm{C}_{20} \mathrm{H}_{32}\right)$ with a similar carbon skeleton was found in the same organism. This prokaryote, naturally occurring in hot spring microbial mats, is considered to be one of the oldest bacterial life forms on earth. Verrucosane-type diterpenoids had previously been detected only in some liverworts (Hepaticae), forming a unique group in the plant kingdom.

\section{Introduction}

Chloroflexus aurantiacus, a filamentous, gliding, thermophilic phototrophic bacterium, is in a number of respects (e.g. ecology, nutrition, photosynthesis, $\mathrm{CO}_{2}$ fixation, bacteriochlorophyll structure) unique among phototrophic bacteria and therefore forms its own taxonomic family, the Chloroflexaceae (Bauld \& Brock, 1973; Madigan et al., 1974; Gloe \& Risch, 1978; Holo \& Sirevåg, 1986; Pierson \& Castenholz, 1991). Most of the phototrophic bacteria are Gram-negative, but recently it has been clearly demonstrated that Chloroflexus lacks not only a characteristic cell wall lipopolysaccharide but also a (lipo)protein in the rigid layer and contains Lornithine as the only diamino acid constituent of the peptidoglycan, properties normally known for Grampositive cells only (Jürgens et al., 1987; Meissner et al., 1988). These findings for the cell wall composition of $C$. aurantiacus are exceptional among phototrophic green bacteria and underline the isolated genealogical position of Chloroflexus (Fox et al., 1980; Gibson et al., 1985). This is additionally confirmed by $16 \mathrm{~S}$ ribosomal RNA cataloguing data. The low $S_{\mathrm{AB}}$ value $(<0.2)$ obtained

*Author for correspondence. Tel. +494041235001 ; fax +4940 41236347. suggests a very early $\left(\approx 3.8 \times 10^{9}\right.$ years $)$ separation of Chloroflexus from other bacteria (Fox et al., 1980; Kandler, 1981).

Chloroflexus occurs naturally in bacterial mats of alkaline hot springs, growing at temperatures between $50{ }^{\circ} \mathrm{C}$ and $70^{\circ} \mathrm{C}$. Although a temperate member of this family from freshwater lakes has been described (Gorlenko, 1975), Chloroflexus-like bacteria are also reported as members of the prokaryotic communities from heliothermal, hypersaline ponds such as Solar Lake, Sinai (Boon et al., 1981; Schidlowsky et al., 1984). In natural environments, Chloroflexus is often associated with cyanobacteria.

The ability to form laminated mats with internal structures resembling Precambrian stromatolites (Doemel \& Brock, 1974) draws attention to the lipid composition of cyanobacteria and of $C$. aurantiacus. That Chloroflexus can produce long-chain unsaturated hydrocarbons with a maximum at $\mathrm{n}-\mathrm{C}_{31: 3}$ and long-chain saturated and unsaturated wax esters in the carbon range $\mathrm{C}_{28}$ to $\mathrm{C}_{38}$ (maximum $\mathrm{C}_{36}$ ) is well known from studies of cell cultures (Knudsen et al., 1982; Shiea et al., 1991; Hefter, 1992). These compounds were also found in recent sediment samples containing Chloroflexus (Boudou et al., 1986; Dobson et al., 1988; Zeng et al., $1992 a, b)$. Halfen et al. (1972) showed that the carotenoid 


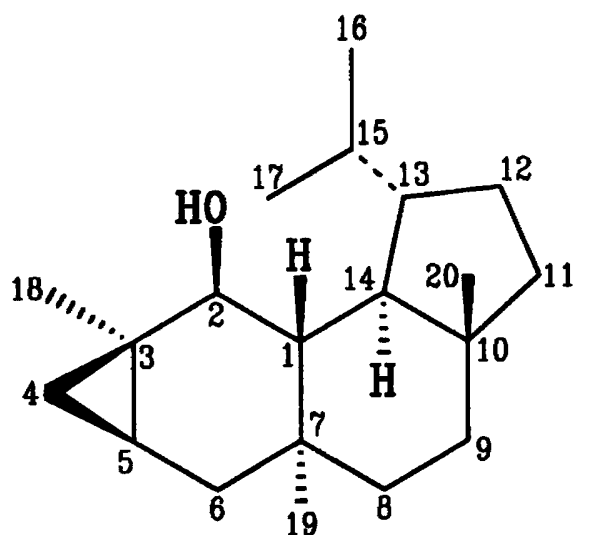

Fig. 1. Structure of (-)-verrucosan-2 $\beta$-ol from $C$. aurantiacus.

composition of Chloroflexus ( $\beta$-carotene, $\gamma$-carotene, $\mathrm{OH}-\gamma$-carotene-glucoside) is distinct from that of other prokaryotic organisms.

Here we report for the first time the isolation and identification of (-)-verrucosan-2 $\beta$-ol (Fig. 1) from $C$. aurantiacus. This type of diterpene has been described previously only in liverworts (Hepaticae), a special group of eukaryotic organisms representing an early stage in the evolution of terrestrial plants (Matsuo et al., 1984).

\section{Methods}

Organism. C. aurantiacus strain Ok70-fl (DSM 636) was grown photoorgano-heterotrophically at $55^{\circ} \mathrm{C}$ and 2000 lux in 1 litre screwcap bottles. The medium (modified after Kaulen \& Klemme, 1983) contained, in 1 litre: $0.1 \mathrm{~g} \mathrm{Na}_{2} \mathrm{HPO}_{4} \cdot 2 \mathrm{H}_{2} \mathrm{O} ; 0.1 \mathrm{~g} \mathrm{MgSO}_{4} .7 \mathrm{H}_{2} \mathrm{O} ; 0.05 \mathrm{~g}$
$\mathrm{CaCl}_{2} .2 \mathrm{H}_{2} \mathrm{O} ; 0.002 \mathrm{~g} \mathrm{FeSO}_{4} .7 \mathrm{H}_{2} \mathrm{O} ; 0.4 \mathrm{~g}$ glycylglycine and $2 \mathrm{~g}$ yeast extract. The $\mathrm{pH}$ was adjusted to $\mathrm{pH} \mathrm{8.2}$. Cells were harvested at the stationary growth phase and washed twice with $0.9 \% \mathrm{NaCl}$ before storage at $-20^{\circ} \mathrm{C}$ until use.

Extraction and purification methods. Freeze-dried cells $(10 \mathrm{~g})$ were extracted ultrasonically for $15 \mathrm{~min}$ in a mixture of dichloromethane/ methanol $(1: 1, v / v)$. Solvents were removed by centrifugation ( $20 \mathrm{~min}$, 2000 r.p.m.) from the remaining cells. Extraction was repeated three times until the solvents were nearly colourless. The combined extracts were evaporated to dryness and separated by column chromatography $(2.5 \times 50 \mathrm{~cm}$; Merck silica gel, $100 \mathrm{mesh})$. Sequential elution with hexane, dichloromethane and a mixture of methanol/dichloromethane /water $(6: 3: 1$, by vol.) gave three fractions. The first contained the known long-chain unsaturated hydrocarbons and small amounts of a verrucosene, the second fraction consisted of the known mixture of wax esters and additionally the verrucosan- $2 \beta$-ol, whereas the third fraction was made up mainly of polar lipids. The verrucosene was purified by thin-layer chromatography with impregnated silica gel (Merck) plates $\left(5 \% \mathrm{AgNO}_{3}\right)$ using $\mathrm{n}$-hexane as developer. The verrucosan- $2 \beta$-ol was separated from the wax esters by thin-layer chromatography (Merck silica gel 60$)$ using a mixture of hexane/dichloromethane $(6: 4, v / v)$ as developer. The band containing the verrucosan- $2 \beta$-ol $\left(R_{F}=0.27\right)$ was scraped off and eluted by dichloromethane from the silica gel for further investigation.

As a control, an extract of the culture medium, prepared using the same methods as for bacteria, was analysed as below. None of the lipids observed in Chloroflexus was found in this extract.

Analytical methods. The content of hopanoid triterpenes in Chloroflexus was examined according to the method described by Rohmer et al. (1984).

GC/MS analyses were performed on a Carlo Erba 4160 gas chromatograph equipped with a fused silica capillary column (DB-5, $30 \mathrm{~m} \times 0.25 \mathrm{~mm}$, J\&W Scientific), coupled to a Varian CH7A spectrometer. MS conditions: $70 \mathrm{eV}$ ionization energy; source temperature $250^{\circ} \mathrm{C}$; mass range $\mathrm{m} / \mathrm{z} 50-800$; resolution 1000 . GC temperature programme: $80^{\circ} \mathrm{C}, 5 \mathrm{~min}$ isothermal; $80-300^{\circ} \mathrm{C}, 3^{\circ} \mathrm{C} \min ^{-1} ; 300^{\circ} \mathrm{C}$,

Table $1 .{ }^{13} \mathrm{C}$ - and ${ }^{1} \mathrm{H}$-NMR data for verrucosan-2 $\beta$-ol from $C$. aurantiacus

Numbering of carbon atoms is indicated in Fig. 1. Coupling constants are shown in brackets.

\begin{tabular}{|c|c|c|c|c|c|}
\hline C-atom & $\delta^{13} \mathrm{C}$ & $\delta^{1} \mathbf{H}$ & $J(\mathrm{~Hz})$ & $\delta^{1} \mathrm{H}$ & $J(\mathrm{~Hz})$ \\
\hline 1 & 46.89 & 0.75 & {$[11 \cdot 0 ; 9 \cdot 5]$} & - & \\
\hline 2 & $73 \cdot 76$ & 3.55 & {$[9 \cdot 5 ; 6 \cdot 5]$} & - & \\
\hline 3 & $23 \cdot 60$ & - & & - & \\
\hline 4 & 18.70 & $0.42(\alpha)$ & {$[8 \cdot 5 ; 4 \cdot 5]$} & $0 \cdot 17(\beta)$ & {$[4 \cdot 5 ; 4 \cdot 5]$} \\
\hline 5 & 21.82 & 0.98 & & - & \\
\hline 6 & $42 \cdot 83$ & $1.77(\alpha)$ & {$[14.0 ; 9 \cdot 5]$} & $1 \cdot 05(\beta)$ & $\cdot$ \\
\hline 7 & 37.32 & - & & - & \\
\hline 8 & 37.93 & $\approx 1 \cdot 38(\beta)$ & & $1 \cdot 14(\alpha)$ & \\
\hline 9 & $35 \cdot 72$ & $\approx 1.38$ & & $\approx 1.30$ & \\
\hline 10 & $44 \cdot 61$ & - & & - & \\
\hline 11 & 41.00 & $1 \cdot 33(\beta)$ & & $0.99(\alpha)$ & \\
\hline 12 & 22.68 & $1.59(\beta)$ & {$[13 \cdot 5 ; 12.0 ; 10.5 ; 8.0]$} & $1 \cdot 44(\alpha)$ & {$[12-13.5 ; 9.0 ; 4.0 ; 0.8]$} \\
\hline 13 & 44.35 & $2 \cdot 00$ & {$[10.5 ; 10.5 ; 4.0 ; 2.5]$} & - & \\
\hline 14 & $48 \cdot 37$ & $1 \cdot 25$ & {$[11.0 ; 10.5]$} & - & \\
\hline 15 & 28.84 & $2 \cdot 14$ & {$[6 \times 6.9 ; 2.5]$} & - & \\
\hline 16 & 23.56 & 0.869 & {$[6 \cdot 9]$} & - & \\
\hline 17 & $15 \cdot 22$ & 0.813 & [6.9] & - & \\
\hline 18 & $25 \cdot 54$ & $1 \cdot 169$ & {$\left[0.5\left({ }^{4} J\right)\right]$} & - & \\
\hline 19 & $19 \cdot 42$ & 0.857 & {$\left[1.0 ; 0.5\left({ }^{4} J\right)\right]$} & - & \\
\hline 20 & 17.97 & 0.723 & {$\left[1.0 ; 0.5\left({ }^{4} J\right)\right]$} & - & \\
\hline
\end{tabular}




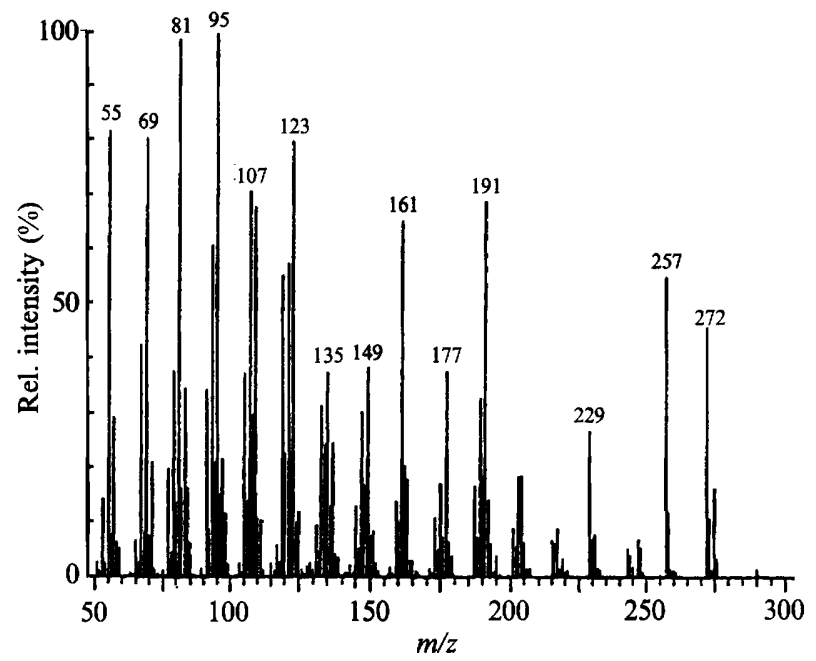

(a)
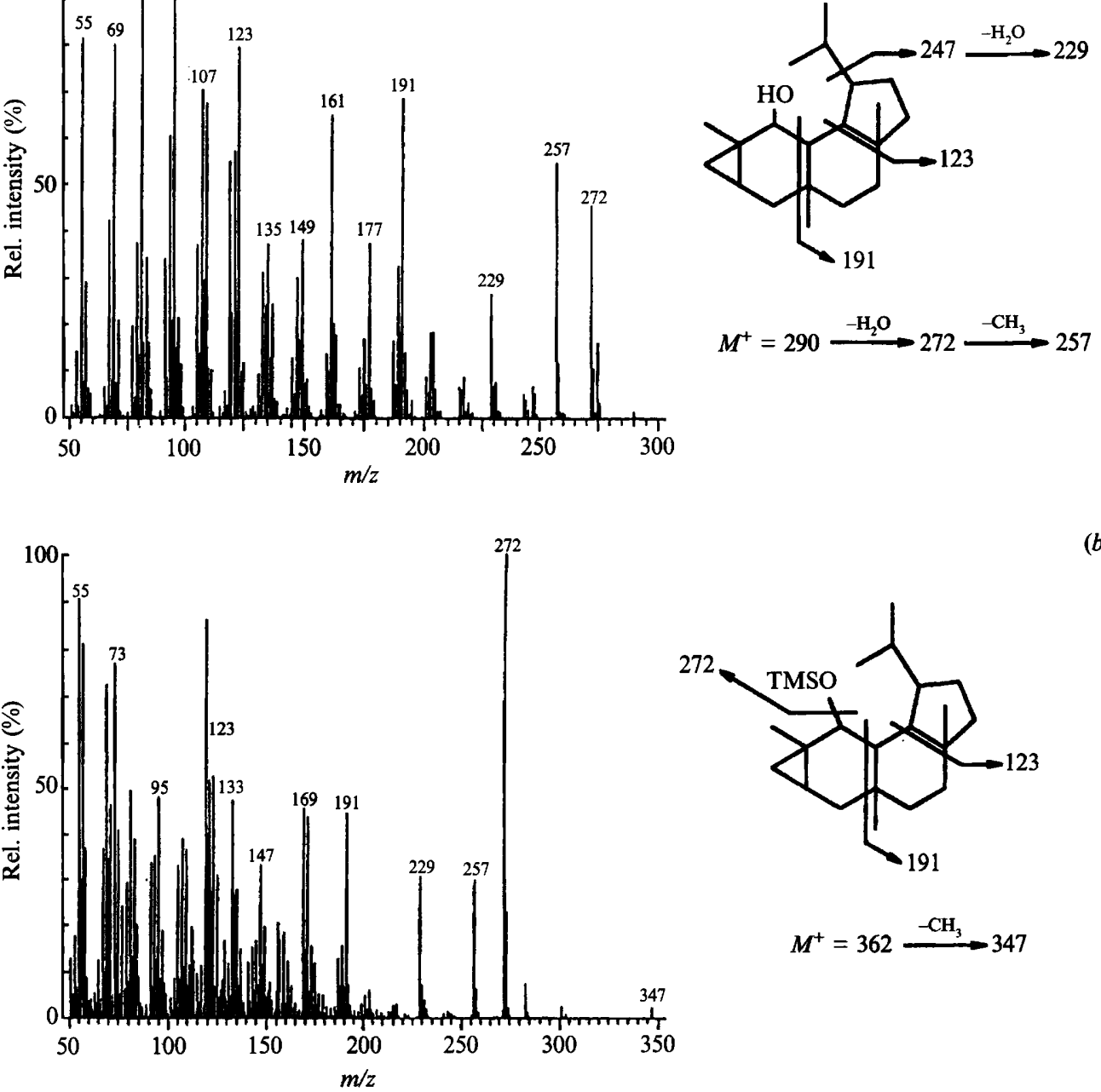

(b)

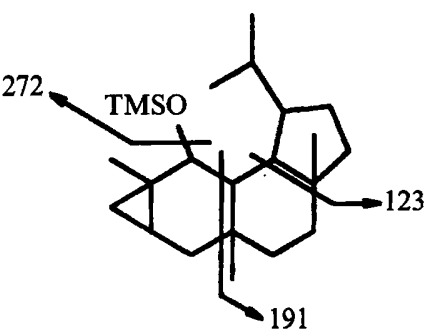

$$
M^{+}=362 \stackrel{-\mathrm{CH}_{3}}{\longrightarrow} 347
$$

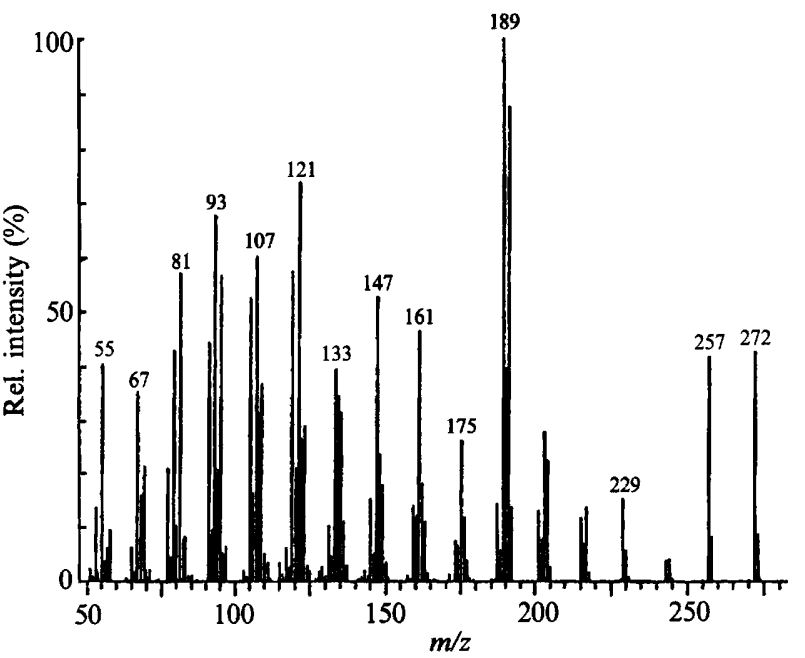

(c)

Fig. 2. Mass spectra of verrucosan-2 $\beta$-ol $(a)$, its TMS-derivative $(b)$ and the verrucosene $(c)$, with structural assignments and explanation of some characteristic fragment ions. 
20 min isothermal; injection mode, on-column; carrier gas, He. For the GC/MS analyses, one sample of the partially purified verrucosan- $2 \beta$-ol was treated with $\mathrm{N}, \mathrm{O}$-bis(trimethylsilyl)trifluoroacetamide (BSTFA) to obtain TMS ethers.

NMR spectroscopy was performed on a Bruker AM 400 spectrometer operating at observation frequencies of 400 and $100 \mathrm{MHz}$ for ${ }^{1} \mathrm{H}$ and ${ }^{13} \mathrm{C}$ nuclei respectively, and data were recorded at $300 \mathrm{~K}$. The chemical shifts $(\delta)$ are reported in p.p.m. from TMS using the solvent $\left(\mathrm{CD}_{2} \mathrm{Cl}_{2} \delta^{1} \mathrm{H} 5 \cdot 32, \delta^{13} \mathrm{C} 53 \cdot 84\right)$ as internal reference. $J$ values result from first-order interpretations and are usually given to the nearest $0.5 \mathrm{~Hz}$. A NOESY experiment was performed with both relaxation delay and mixing times set at $1.5 \mathrm{~s}$. For inverse long-range ${ }^{1} \mathrm{H}-{ }^{13} \mathrm{C}$ correlation experiment, the $J$-selection delay was tuned for ${ }^{n} j_{\mathrm{CH}}=7 \mathrm{~Hz}$.

The optical rotations were measured in $\mathrm{CHCl}_{3}$ solutions at $24^{\circ} \mathrm{C}$ on a Perkin-Elmer $241 \mathrm{MC}$ polarimeter.

\section{Results and Discussion}

(-)-Verrucosan-2 $\beta$-ol isolated from $C$. aurantiacus was identified by NMR studies $\left({ }^{1} \mathrm{H}-\mathrm{NMR},{ }^{13} \mathrm{C}-\mathrm{NMR},{ }^{1} \mathrm{H}\right.$ broad band decoupled and DEPT spectra, phasesensitive ${ }^{1} \mathrm{H}-{ }^{1} \mathrm{H}$ COSY and NOESY, inverse one-bond and long-range $\left({ }^{2,3} J_{\mathrm{CH}}\right){ }^{1} \mathrm{H}-{ }^{13} \mathrm{C}$ correlation experiments) which also allowed complete assignment of proton and carbon chemical shifts (Table 1). Data recorded are in full agreement with those reported in the literature for (-)-verrucosan-2 $\beta$-ol and related compounds (Eguchi $e t$ al., 1982; Kubo et al., 1984; Matsuo et al., 1984; Fukuyama et al., 1988).

The absolute configuration of the isolated product and the (-)-verrucosan- $2 \beta$-ol in liverworts was found to be identical. The measurements of optical rotation gave an $[\alpha]_{\mathrm{D}}$ value of $-56^{\circ}$ for the compound present in $C$. aurantiacus. Matsuo et al. (1984) obtained an $[\alpha]_{D}$ value of $-58^{\circ}$ for the liverwort compound.

The mass spectral fragmentation pattern of the verrucosan-2 $\beta$-ol, its TMS-derivative and of the verrucosene are presented in Fig. 2. Due to the similarities of the mass spectroscopic fragmentation patterns of the verrucosene and the verrucosanol, a similar carbon framework of both compounds can be assumed. The molecular ion $(m / z$ 272) of the verrucosene leads to the elemental composition $\mathrm{C}_{20} \mathrm{H}_{32}$, which is in accordance with a verrucosene possessing one double bond. In comparison with the verrucosan- $2 \beta$-ol, a shift of two mass units in the mass spectrum of the verrucosene can be observed (e.g. $191 \rightarrow 189,177 \rightarrow 175,149 \rightarrow 147,123$ $\rightarrow 121$ ), which supports the presence of one double bond in a similar carbon framework. Detailed localization of the double bond in the verrucosene is not possible from the mass spectral analysis alone, because a double bond migration from the isopropyl side-chain into the ring system primary to the fragmentation can occur, analogous to results found for diploptene (Bird et al., 1971). Therefore, NMR structural elucidation of this compound is in progress. This is, to our knowledge, the first report of verrucosane-type diterpenoids in a prokaryotic organism. The content of verrucosan- $2 \beta$-ol in $C$. aurantiacus was $1.76 \mathrm{mg}$ per $\mathrm{g}$ dry weight of cell material. This is the same order of magnitude as the content of hopanoid-type triterpenes [0.1-2 mg (g dry wt $)^{-1}$; Rohmer et al., 1984] usually occurring in different prokaryotes. The similarity might indicate that the verrucosanol in Chloroflexus is a membrane constituent, comparable to hopanoids in other bacteria. Using the method of Rohmer et al. (1984), positive proof for the presence of hopanoid triterpenes in $C$. aurantiacus was not found, nor could steroids be detected during our analyses.

The chemical structure of the verrucosan- $2 \beta$-ol points to a completely different pathway of lipid biosynthesis, compared to the synthesis of hopanoids in prokaryotes or steroids in eukaryotes (Ourisson et al., 1979). Therefore, verrucosan- $2 \beta$-ol might be of chemotaxonomic importance reflecting the special phylogenetic position of the Chloroflexaceae. However, the absence of hopanoids could reflect an earlier stage of biochemical evolution in comparison to the hopanoid-containing prokaryotes. Thus, the discovery of verrucosan- $2 \beta$-ol in this organism extends the significance of verrucosanetype molecules as biomarkers for early prokaryotic life forms and chemotaxonomic relationships. Although the biological function of the verrucosene is not clear, it could well represent a biosynthetic intermediate or precursor of the oxygen-functionalized verrucosan- $2 \beta$-ol. No reports of such verrucosenes are known from the liverworts or other organisms.

To our knowledge, no reports of verrucosane-type compounds exist from recent or ancient sediments, not even from environments which have been described to contain cells of Chloroflexus. Recently, Zeng et al. $(1992 b)$ reported an unidentified compound with a comparable retention time as the verrucosanol in an apolar lipid fraction from Octopus Spring cyanobacterial mats containing Chloroflexus, but unfortunately, they did not determine the chemical structure of this compound. Further investigations on the biomarker potential of verrucosanes for Chloroflexaceae in recent and ancient sediments are in progress.

The authors thank Miss Imke Notholt for experienced technical assistance.

\section{References}

Bauld, J. \& BRock, T. D. (1973). Ecological studies of Chloroflexis, a gliding photosynthetic bacterium. Archives of Microbiology 92, 267-284.

BIRD, C. W., LYNCH, J. M. \& REID, W. W. (1971). The identification of hop-22(29)-ene in prokaryotic organisms. Tetrahedron Letters 34, $3189-3190$. 
Boon, J. J., Hines, H., Burlingame, A. L., Klok, J., Rijpastra, I. C., DE Leeuw, J. W., Edmund, K. E. \& Eglinton, G. (1981). Organic geochemical studies of Solar Lake laminated cyanobacterial mats. In Advances in Organic Geochemistry, pp. 207-227. Edited by M. Bjory and others. Chichester: John Wiley.

Boudou, J. P., Trichet, J., Robinson, N. \& Brassel, S. C. (1986). Lipid composition of a recent Polynesian microbial mat sequence. Organic Geochemistry 10, 705-709.

Dobson, G., Ward, D. M., Robinson, N. \& Eglinton, G. (1988). Biogeochemistry of hot spring environments : extractable lipids of a cyanobacterial mat. Chemical Geology 68, 155-179.

DOEMEL, W. N. \& BROCK, T. D. (1974). Bacterial stromatolites: origin of laminations. Science 184, 1083-1085.

Eguch, S., Matsuo, A., Nakayama, M., Takaoka, D. \& Hayashi, S. (1982). Mass spectra of some diterpenoids with the novel carbon skeletons verrucosane, neoverrucosane and homoverrucosane. Shitsuryo Bunseki 30, 325-335.

Fox, G. E., Stackebrandt, E., Hespell, R. B., Gibson, J., Maniloff, J., Dyer, T. A., Wolfe, R. S., Balch, W. E., TANner, R. S., MAGRUM, L. J., ZABLEN, L. B., Blakemore, R., GuPta, R., BoneN, L., Lewis, B. J., Stahl, D. A., Luehrsen, K. R., Chen, K. N. \& WOESE, C. R. (1980). The phylogeny of prokaryotes. Nature, London 290, 457-463.

Fukuyama, Y., Masuya, T., ToRI, M., Kido, M., Wakamatsu, M. \& Asakawa, Y. (1988). Verrucosane diterpene from the liverwort Plagiochila stephensoniana. Phytochemistry 27, 1797-1799.

Gibson, J., Ludwig, W., Stackebrandt, E. \& Woese, C. R. (1985). The phylogeny of the green photosynthetic bacteria: absence of a close relationship between Chlorobium and Chloroflexus. Systematics and Applied Microbiology 6, 152-156.

GLOE, A. \& Risch, N. (1978). Bacteriochlorophyll $c_{s}$, a new bacteriochlorophyll from Chloroflexus aurantiacus. Archives of Microbiology 118, 153-156.

GoRLENKo, V. M. (1975). Characteristics of filamentous phototrophic bacteria from freshwater lakes. Microbiology [English translation of Mikrobiologiya] 44, 682-684.

Halfen, L. N., Pierson, B. K. \& Francis, G. W. (1972). Carotenoids of a gliding organism containing bacteriochlorophylls. Archives of Microbiology 82, 240-246.

HeFTER, J. (1992). Biogeochemie rezenter Mikrobialithe. PhD, Institut für Biogeochemie und Meereschemie, Universität Hamburg.

Holo, H. \& SIREVÅ, R. (1986). Autotrophic growth and $\mathrm{CO}_{2}$-fixation of Chloroflexus aurantiacus. Archives of Microbiology 145, 173-180.

JÜRgENS, U. J., MEISSNER, J., FisChER, U., KÖNIG, W. A. \& WeCKESSER, J. (1987). Ornithine as a constituent of the peptidoglycan of Chloroflexus aurantiacus, diaminopimelic acid in that of Chlorobium vibriforme f, thiosulfatophilum. Archives of Microbiology 148, 72-76.
KANDLER, O. (1981). Archaebakterien und Phylogenie der Organismen. Naturwissenschaften 68, 183-192.

KaUleN, H. \& KLEMmE, J. H. (1983). No evidence of covalent modification of glutamine synthetase in the thermophilic phototrophic bacterium Chloroflexus aurantiacus. FEMS Microbiology Letters 20, 75-79.

Knudsen, E., Jantzen, E., Bryn, K., Ormerod, J. G. \& Sirevåg, R. (1982). Quantitative and structural characteristics of lipids in Chlorobium and Chloroflexus. Archives of Microbiology 132, 149-154.

Kubo, I., Matsumoto, A., Hirotsu, K., Naoki, H. \& Wood, W. F. (1984). Structure and the absolute configuration of a new diterpene, (-)-2(S),(R)-dihydroxyverrucosane, from the liverwort Gyrothyra underwoodiana. Journal of Organic Chemistry 49, $4644-4646$.

Madigan, M. T., Petersen, S. R. \& Brock, T. D. (1974). Nutritional studies on Chloroflexus, a filamentous photosynthetic, gliding bacterium. Archives of Microbiology 100, 97-103.

Matsuo, A., Atsumi, K. \& NaKayama, M. (1984). Isolation of seven verrucosane diterpenoids from the liverwort Scapania bolanderi. Zeitschrift für Naturforschung 39b, 1281-1285.

Meissner, J., Krauss, J. H., Jürgens, U. J. \& Weckesser, J. (1988) Absence of a characteristic cell wall lipopolysaccharide in the phototrophic bacterium Chloroflexus aurantiacus. Journal of Bacteriology 170, 3213-3216.

Ourisson, G., Albrecht, P. \& Rohmer, M. (1979). The hopanoids: palaeochemistry and biochemistry of a group of natural products. Pure and Applied Chemistry 51, 709-729.

Pierson, B. K. \& Castenholz, R. W. (1991). The family Chloroflexaceae. In The Prokaryotes, pp. 3754-3774. Edited by A. Balows, H. G. Trüper, M. Dworkin, W. Harder \& K. H. Schleifer. New York: Springer.

Rohmer, M., Bouvier-Nave, P. \& Ourisson, G. (1984). Distribution of hopanoid triterpenes in prokaryotes. Journal of General Microbiology 130, 1137-1150.

Schidlowsky, M., Matzigkeit, U. \& Krumbein, W. E. (1984). Superheavy organic carbon from hypersaline microbial mats. Naturwissenschaften 71, 303-308.

ShIEA, J., Brassel, S. C. \& WARD, D. M. (1991). Comparative analysis of extractable lipids in hot spring microbial mats and their component photosynthetic bacteria. Organic Geochemistry 17, 309-319.

ZenG, Y. B., Ward, D. M., Brassel, S. C. \& Eglinton, G. (1992a). Biogeochemistry of hot spring environments. 2. Lipid compositions of Yellowstone (Wyoming, U.S.A.) cyanobacterial and Chloroflexus mats. Chemical Geology 95, 327-345.

Zeng, Y. B., Ward, D. M., Brassel, S. C. \& Eglinton, G. (1992b). Biogeochemistry of hot spring environments. 3. Apolar and polar lipids in the biologically active layers of a cyanobacterial mat. Chemical Geology 95, 347-360. 